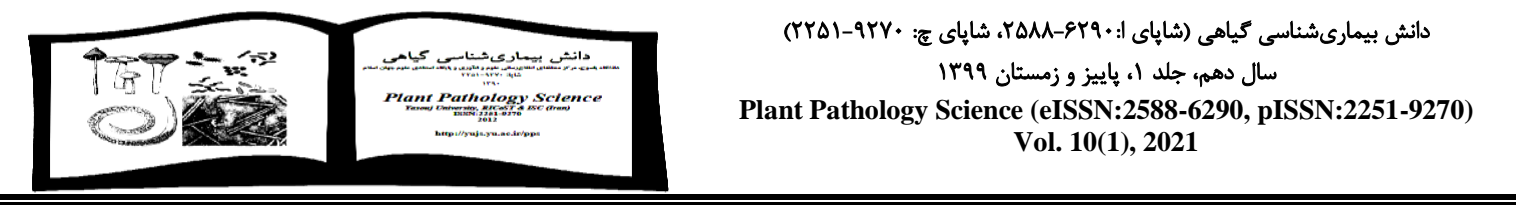

Extensional Article

\title{
Plant diseases management in organic agriculture
}

\author{
ZAHRA SALIMI, MARYAM MIRTALEBI ${ }^{\bowtie}$ \\ Department of Plant Protection, College of Agriculture, Shiraz University, Shiraz, Iran \\ Received: 03.03.2021 \\ Accepted: 12.05.2021 \\ Salimi Z, Mirtalebi M (2021) Plant diseases management in organic agriculture. Plant \\ Pathology Science 10(1):128-140. Doi: 10.2982/PPS.10.1.128.
}

\begin{abstract}
Today the ecological, ecological and sociological problems of conventional agriculture are of great concern. Accordingly, organic farming should be viewed as an alternative approach that provides safe and healthy nutrition by eliminating synthetic pesticides and fertilizers with the least loss of nutrients and energy and the least negative impact on the environment. Organic farming is guided by the idea that all processes within an agroecosystem are interdependent and it aims to achieve efficiency, diversity, selfsufficiency, self-regulation and resilience through natural processes using the ecological possibilities of the agricultural system. Disease management in organic farming is based on maintaining biodiversity and soil health. In this review, a brief description of organic farming is given first. The next other practices used in organic farming to control disease include sanitation, organic soil improvement, long-term crop rotations, reduced tillage, the right harvesting time, the selection of crops and varieties, and the use of catch crops and also, catch crop cultivation. In conclusion, organic farming has the potential to improve the recycling of biomass and optimize the availability of nutrients and ensure favorable soil conditions for plant growth.
\end{abstract}

Key words: Biological diversity, Disease suppression, Soil health

$\triangle$ Corresponding author: mmirtalebi@shirazu.ac.ir 
مقاله ترويجى

\title{
مديريت بيمارىهاى كياهى در كشاورزى أركانيك
}

\author{
زهرا سليمى، مريمم ميرطالبى \\ بخش گياه يزشكى، دانشكده كشاورزى، دانشگاه شيراز

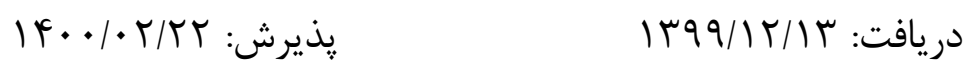

سليمى ز، ميرطالبى م (99 (1)) مديريت بيمارىهاى گياهى در كشاورزى أرَانيك. دانش بيمارى

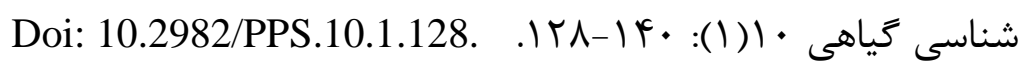

جكيده

امروزه مشكلات بومشناختى، زيستمحيطى و جامعهشناختى مرتبط با كشاورزى مرسوم بسيار نكران كننده است. بر اين اساس، كشاوزى اُركانيك بايد بهعنوان يك روش جايخزين مورد توجه قرار گيرد كه با عدم وجود سموم شيميايى و كودهاى مصنوعى و با كمترين اتلاف عناصر غذايى و انرزى و همجنين كمترين اثرات منفى روى محيطزيست، غذاى سالم را فراهم مى كند. كشاورزى أركانيك با اين ايده كه تمام فرآيندهاى درون يك نظام زراعى به هم وابستهاند، اداره مىشود و هدف آن دستيابى و حمايت از كارايى، تنوع، خودكفايى، خودتنظيمى و بركشتيذيرى از طريق فرآيندهاى طبيعى با استفاده از امكانات بومشناختى نظام كشاورزى است. مديريت بيمارى در كشاورزى أرَحانيك بر اساس حفظ تنوع زيستى و سلامت خاك است. در اين بررسى، ابتدا شرح مختصرى از كشاورزى أركانيك ارائه مىشود. سيس روشهايى شرح داده مىشوند كه در كشاورزى أر كانيك براى مديريت بيمارىها از آنها استفاده مى گردد؛ مانند بهداشت زراعى، اصلاحات آلى خاك، تناوب طولانىمدت، كاهش خاىورزى، زمان مناسب كشت، انتخاب رقم مناسب و استفاده از گياهان يوششى و كشت مخلوط. بهطور

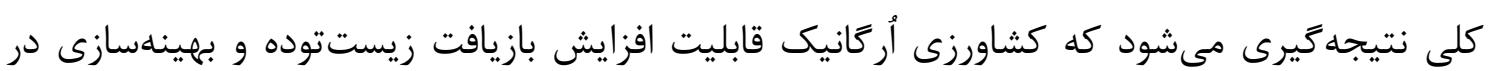
دسترس بودن مواد غذايى و ايجاد شرايط مناسب خاى براى رشد گياه را دارد. وازگًان كليدى: تنوع زيستى، سركوب بيمارى، سلامت خاك

\section{مقدمه}

رشد سريع جمعيت جوامع بشرى و افزايش تقاضا براى مواد غذايى در قرون گذشته تحولى شَرف در كشاورزى مرسوم (Conventional agriculture) ايجاد كرده است؛ اما در دهdهاى اخير افزايش مصرف

$\triangle$ نويسنده مسئول: mmirtalebi@shirazu.ac.ir 
بىرويه نهادهها (Inputs) مانند سموم و كودهاى شيميايى، افزايش هزينههاى توليد، تخريب و فرسايش شيميايى خاك، تخريب زيستى خاك، كاهش شديد منابع توليد و ضعف برنامها و روشهاى اجرايى و ترويجى در توسعه كشاورزى گايدار منجر به بحرانى در امنيت غذايى جهان شده است. وجود جنين مشكلاتى در كشاورزى مرسوم، موجب شكل

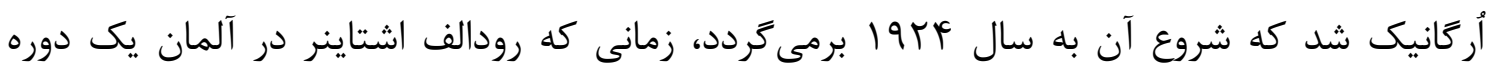

آموزشى مبانى علمى و اجتماعى توسعه كشاورزى بر خزار كرد (Shi-Ming and Sauerborn 2006). كشاورزى اُركانيك شاخهاى از كشاورزى پايدار است كه در آن كاربرد مواد شيميايى و مصنوعى ممنوع است و تمام مراحل توليد، فراورى و بازاريابى محصولات تحت يوشش استانداردهاى مرجع أر كانيك (Organic reference standards)، مديريت و گواهى مىشود. حفظ تنوع زيستى مبناى توليد در اين كشاورزى است و استفاده از تناوب بسيار مهرم است. از نهادههاى سنتز شده مانند كودهاى شيميايى، آفتششها، علف كشها، كياهان اصلاح شده زنتيكى، مواد افزودنى و تابش يرتوها استفاده نمىشود. منابع غيرقابل بازيافت كمتر و منابع محلى بيشتر مورد استفاده قرار مى گيرد. رعايت اين اصول باعث

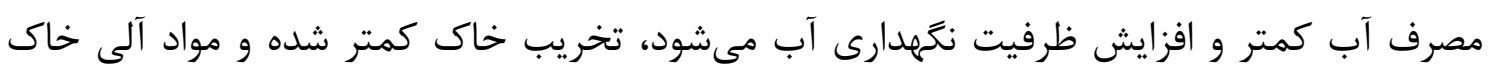
افزايش مىيابد(شكل () و از انرزى كمترى استفاده مى گردد (Furtak and Gałązka 2019).

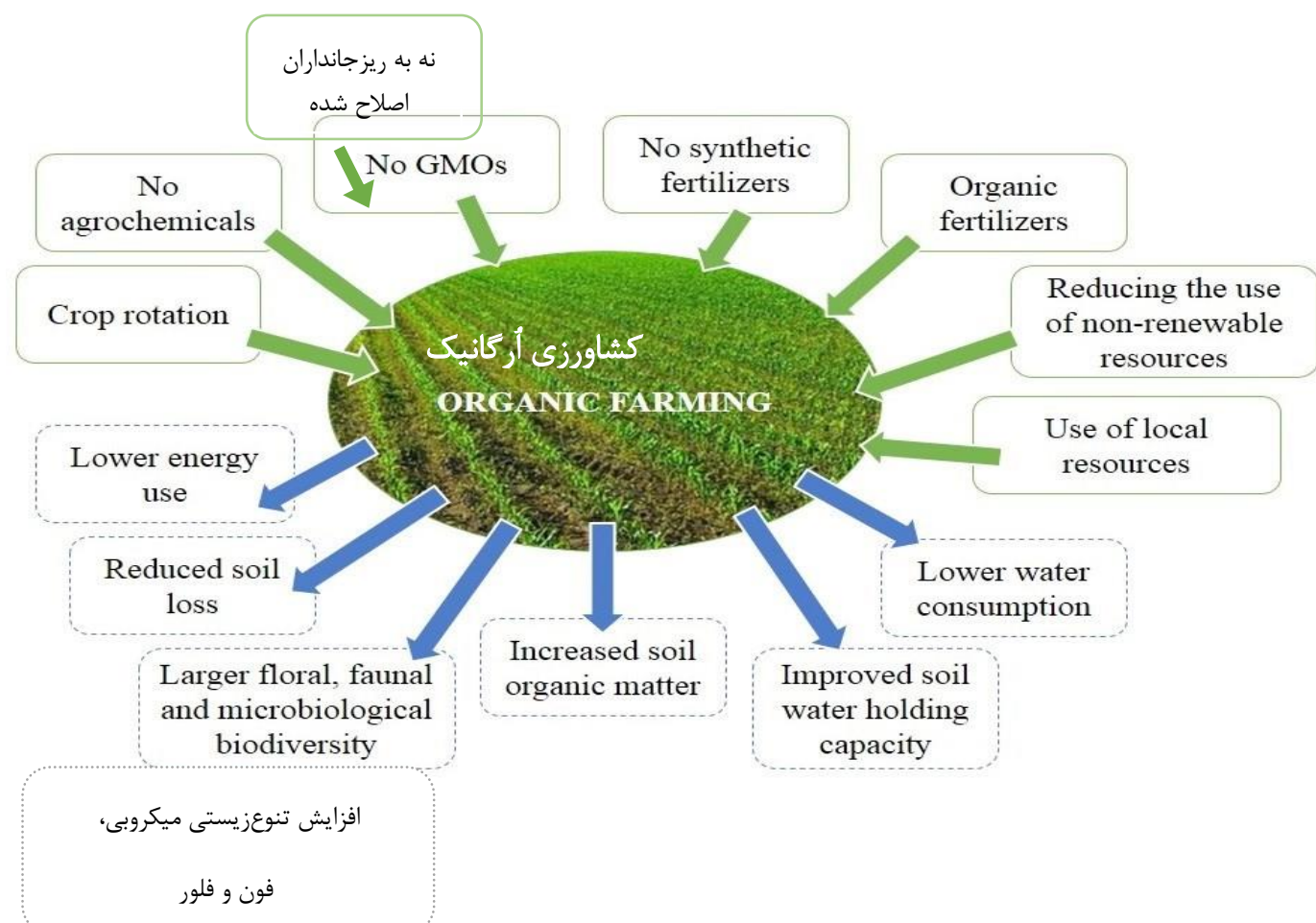

شكل (. اصول و اثرات اصلى كشاورزى اُر عانيك (Furtak and Gałązka 2019) Figure 1. The main principles and effects of organic farming (Furtak and Gałązka 2019) 


\section{تعريف كشاورزى أركانيك و آمار جهانى آن}

فدراسيون بينالمللى جنبشهاى كشاورزى اُركانيك ( International Federation of Organic (Agricultural Movements=IFOAM در سال ^ • • ب ميلادى كشاورزى أر كانيك را اين كونه تعريف كرده است: كشاورزى أركانيك يك نظام توليدى است كه سلامت خاك، بومنظام (Ecosystem) و مردم را حفظ مى كند. اين نظام به جاى استفاده از نهادهاى داراى اثرهاى مشكلزا، به فرايندهاى بومشناختى (Ecological processes)، تنوع زيستى و جرخههاى متناسب با شرايط محلى متكى است. كشاورزى أركانيك تركيبى از سنت، نوآورى و علم است تا از محيط مشترك بهره مند شود و روابط عادلانه و كيفيت زندگى خوب را براى همه افراد درگير ارتقا دهد. براساس آخرين آمار جهانى كشاورزى أركانيك كه در سال 9 ا•r ميلادى توسط فدراسيون بينالمللى جنبشهاى كشاورزى أرَحانيك و موسسه تحقيقات كشاورزى أر كانيك ( Forschungsinstitut für Biologischen Landbau

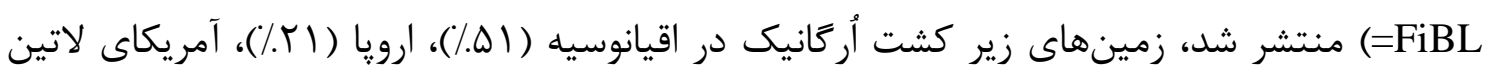
(9 (1/)، آسيا (9./)، آمريكاى شمالى (ه./) و آفريقا (ب//) از كل زمينهاى زير اين كشت در جهان مى باشد. در ايران در سال ه • •r ميلادى، سطح زير كشت أركانيك صفر و در سال IV إr، سطح زير

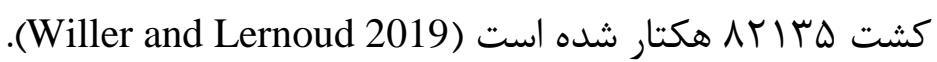

\section{رويكردهاى كشاورزى أركانيك}

كشاورزى أركانيك به نوعى با كشاورزى بومشناختى در ارتباط است كه به معناى به كار بردن مبانى، روشها و رويكردهاى بومشناختى در بومنظامهاى كشاورزى است (Magdoff 2007). بومشناسى يك علم فراموش شده در تحقيقات و آموزش كشاورزى است و جامعه كشاورزى اعم از (ecology) كشاورزان، محققين و دانشجويان كشاورزى از مفاهيم بومشناسى و نقاط قوت بومنظامهاى طبيعى مانند كارايى (Efficiency)، تنوع (Diversity)، خودكفايى (Self-sufficiency)، خودتنظيمى (-Self-) (regulation نظام كشاورزى اُرَانيك معمولاً داراى تنوع بالاتر گياه در زمان و مكان، ميزان بالاترى از مواد آلى خاى و زيست توده، فعاليت ميكروبى بيشتر، تنوع بالاتر ميكروار كانيسمها و جانوران موجود در داخل خاى و سطح زمين، افزايش كارايى مصرف آب از طريق افزايش ظرفيت نتحهدارى آب، كاهش روانآب و افزايش عمق ريشهزايى، بهبود ظرفيت تبادل كاتيونى و افزايش جرخه غذايى داخلى است ( Swer et al. 2011 (al). در كشاوزى أركانيك جندين هدف مشخص شده مانند كار با نظامهاى طبيعى به جاى سلطه بر آنها، تقويت جرخههاى زيستى در نظام كشاورزى، كشاورزى در يك نظام بسته كه در اين نظام تمامى مواد آلى موجود در مزرعه دوباره به خاى برگردانده مىشود، جلوگيرى از انواع آلودگى 
حاصل از كشاورزى، حفظ تنوع زنتيكى محصولات در نظام كشاورزى و محيط طبيعى اطراف آن بر

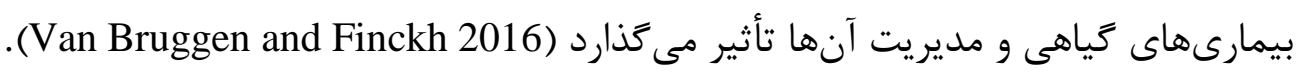

\section{مديريت بيمارىهاى كياهى در كشاورزى أركانيك}

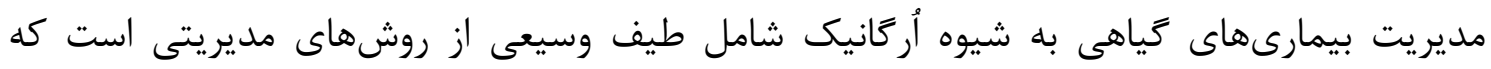
موجب حفظ سلامت و تقويت نقاط قوت بومنظام مىشود (Magdoff 2007). سه رويكرد اساسى براى مديريت بيمارىها در نظام كشاورزى أركانيك وجود داردكه عبارتند از: الف) كاهش مايه اوليه بيماركَ، ب) فراهم كردن شرايط مساعد براى رشد كَياه و به حداقل رساندن شرايط مناسب ميزبان و محيط اطراف آن براى آلودگى و توليدمثل بيماركر، ج ) استفاده از روشهاى درمانى كه كَترش بيشتر

بيمارى را محدود كند (Van Bruggen and Finckh 2016 ). كاهش زادمايه اوليه: مايه اوليه را مىتوان با از بين بردن بقاياى گياهى آلوده، روشهاى مختلف

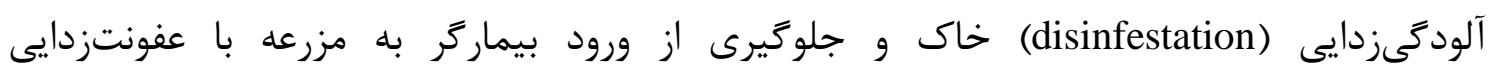
بذر و ساير اندامهاى رويشى كاهش داد. (disinfection)

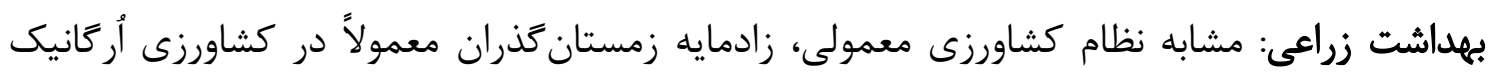

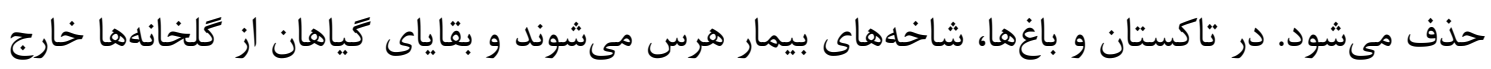
مىشوند. شاخها و بقايا به جاى سوختن كميوست مىشوند تا انتشار خاك بازكردانده شود. يوشاندن يا از بين بردن بقاياى گياهى و حذف كياهان خودرو و ميزبانهاى

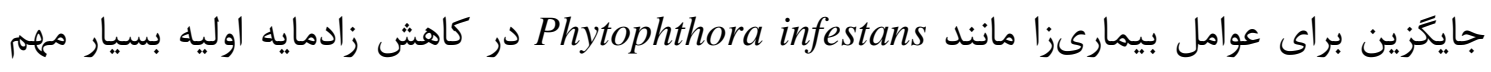
آلودَىزدايى خاك: در كشاورزى أركانيك از جندين روش آلودگىزدايى خاك مانند غرقاب كردن، بخاردهى خاك، آفتابدهى، آلودكىزدايى بىهوازى (يا زيستى) خاك ( Anaerobic (or Biological) (Soil Disinfestation ASD

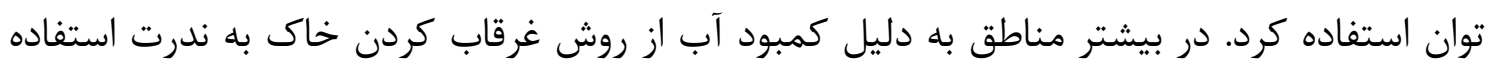

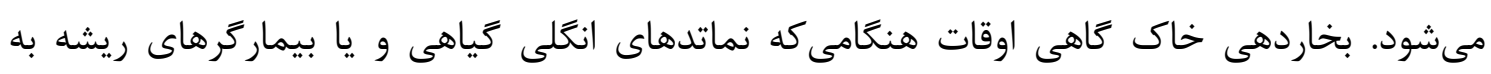
دليل تناوب محدود محصولات با ارزش در كلخانهها مشكلساز مىشوند، استفاده مى گردد. بخاردهى

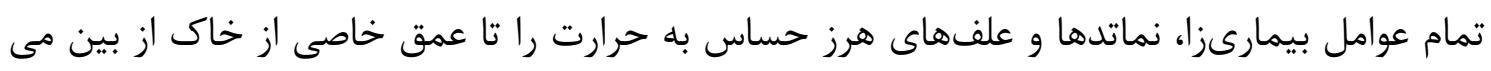

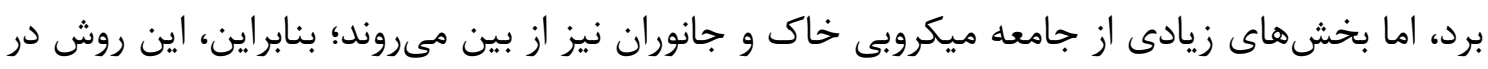

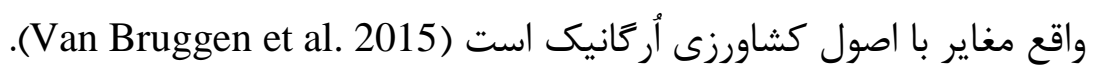


در آفتابدهى، خاك مرطوب با يلاستيك شفاف و مقاوم در برابر اشعه ماوراء بنفش يوشانده شده و براى جند هفته در معرض نور خورشيد قرار مى گيرد. اكثر قارجهاى بيماركر زياهى، باكترىها و

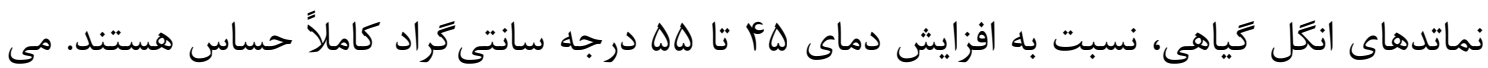

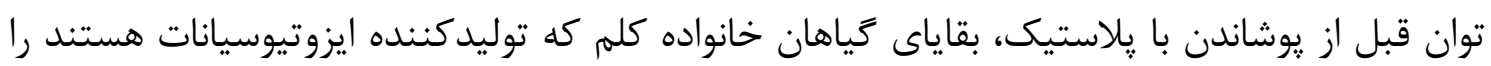
به خاى اضافه كرد و اثر آفتابدهى را افزايش داد. همراه با اثرات گرماى مستقيهم بر بيمارگرها، آفتابدهى خاى همجنين مى تواند با افزايش در دسترس بودن مواد غذايى معدنى و بهبود خصوصيات فيزيكى خاى رشد كياه را افزايش دهد (Saloum and Almahasneh 2015). براى آلودگىزدايى بىهوازى خاك، مواد آلى تازه به خاى اضافه مىشود و خاى مرطوب به مدت سه تا شش هفته توسط پيلاستيك ضد نفوذ هوا يوشيده مىشود. تكثير باكترىها، اكسيرن موجود را تخليه مى كند و در اين شرايط باكترىهاى بىهوازى به تجزيه منبع كربن ادامه مىدهند. تركيبات سمى، از جمله الكلها، آلدهيدها، اسيدهاى آلى و ساير تركيبات فرار، تجمع يافته و اسيديته خاى بـ كاهش مىيابد كه بر بقاى بيمارگرهاى خاكزاد تأثير مى گذارد. باكترىهاى بىهوازى مانند Bacillus و همجنين ممكن است در غيرفعال شدن بيماركرها نقش داشته باشند. ضدعفونى بى هوازى خاك در مهار بسيارى از قارجها، باكترىها و نماتدهاى بيماركر زياهى خاكزاد، از جمله ‘Ralstonia ‘Phytophthora ‘Sclerotinia ،Verticillium ‘Fusarium ‘Rhizoctonia Globodera،Meloidogyne ميكروبى از خصوصيات ضدعفونى بى هوازى خاك است كه مىتواند باعث بازدارندكى عمومى بيمارى هايى باشد كه جندين سال فعال باقى ماندهاند. برخلاف بخاردهى خاك و ضد عفونى شيميايى خاى كه منجر به خلاء بيولوزيكى مىشود، خطر افزايش قابل توجه بيماركرهاى خاكزاد بعد از استفاده از ضدعفونى بى هوازى خاى كاهش مىيابد. تدخين زيستى شامل اصلاح خاك با افزودن تركيبات آلى به خاك و در نتيجه توليد تركيبات فرار مشتق شده زيستى از آنها است كه براى ميكرواركانيسمهاى خاى سمى هستند. براى اين نوع آلودگىزدايى از برخى گياهان خصوصاً گياهان خانواده كلم كه داراى كلوكوزينولاتها هستند به عنوان كود سبز استفاده مىشود. كاربرد بقاياى حيوانى كه ازت زيادى دارند، مانند كود دامى، مىتواند منجر به توليد گاز آمونياك شود كه براى طيف گستردهاى از عوامل بيمارىزا و نماتدهاى بيمارگر، سمى است (Cohen 2005).

جلوگيرى از ورود بيمارگرها در مزرعههاى أرگانيك: بذرها و ساير اندامهاى گياهى كه در توليد محصولات اُركانيك مورد استفاده قرار مى گيرند، بايد از منابع أرَانيك گواهى شده، در صورت موجود 
بودن، منشأ بخيرند. بايد از ميوهها با استفاده از روشهاى طبيعى مانند روش تخمير، بذرهاى أركانيك

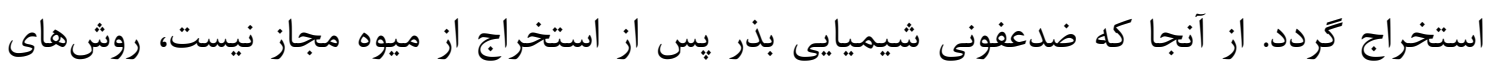

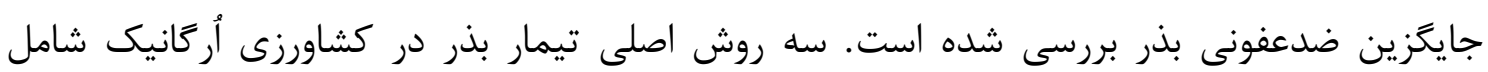

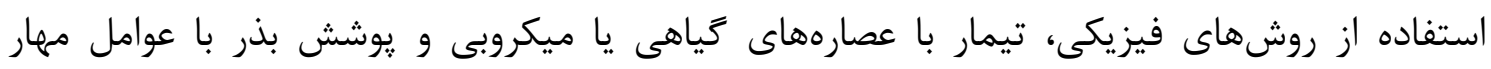

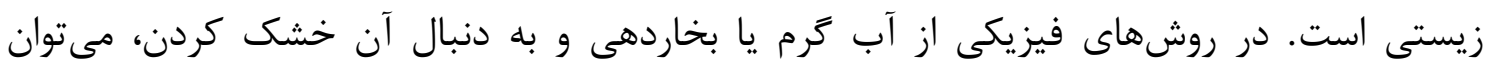

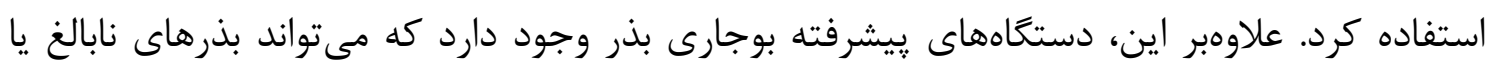

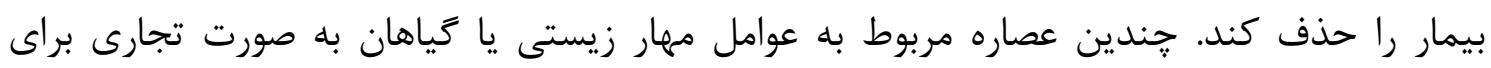

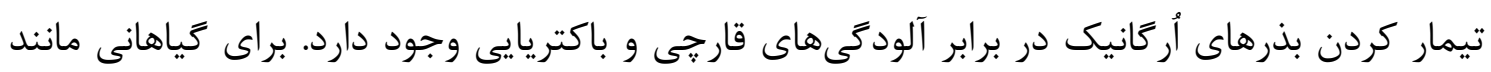

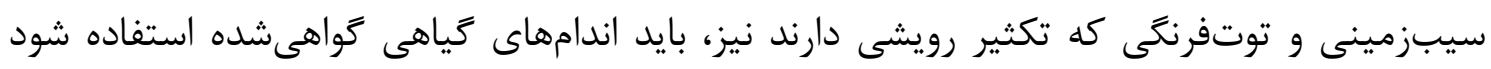

.(Van Bruggen et al. 2015)

جداسازى زمانى و مكانى: كياهان ميزبان حساس را مىتوان در زمان يا مكان با هدف تشكيل يك مانع براى تجمع زادمايههاى بيماركر جدا كرد. جداسازى زمانى به روشهاى مختلف از جمله تنظيم زمان كاشت محصول، انتخاب رقمهاى زودرس يا

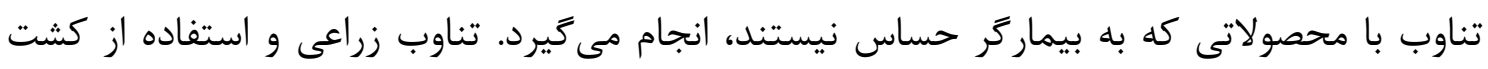
مخلوط (Intercropping)، رايجترين روش جداسازى زمانى است و از راههاى مختلف مانند تغيير

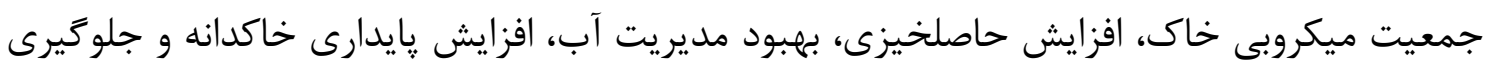
از فرسايش خاك باعث بهبود كيفيت خاك و كاهش بيمارى مىشود. از كياهان علوفهاى تيره

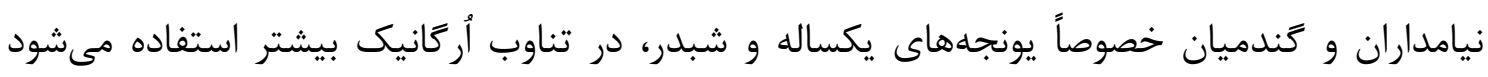

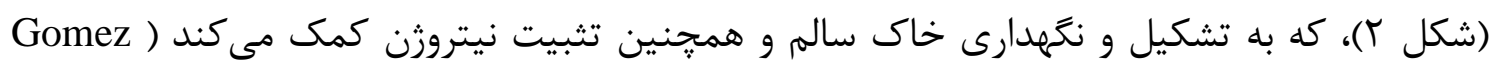
.(and Thivant 2017 با اين حال، اكر بيماركر در مسافتهاى طولانى توسط باد منتقل شود، داراى دامنه ميزبانى وسيع يا

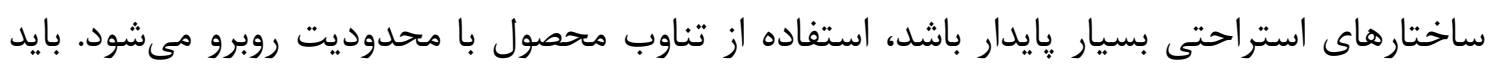

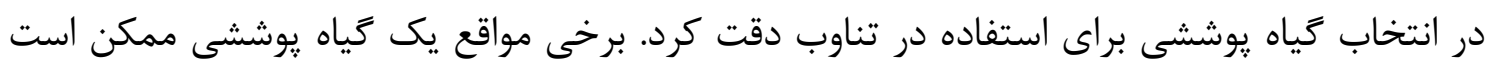

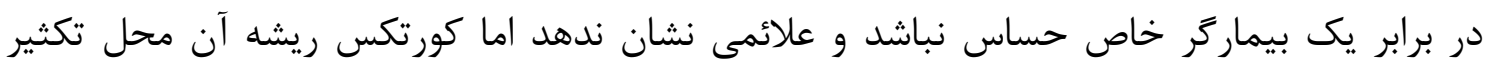

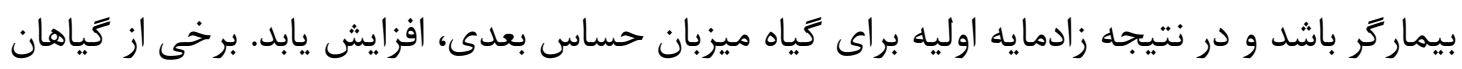




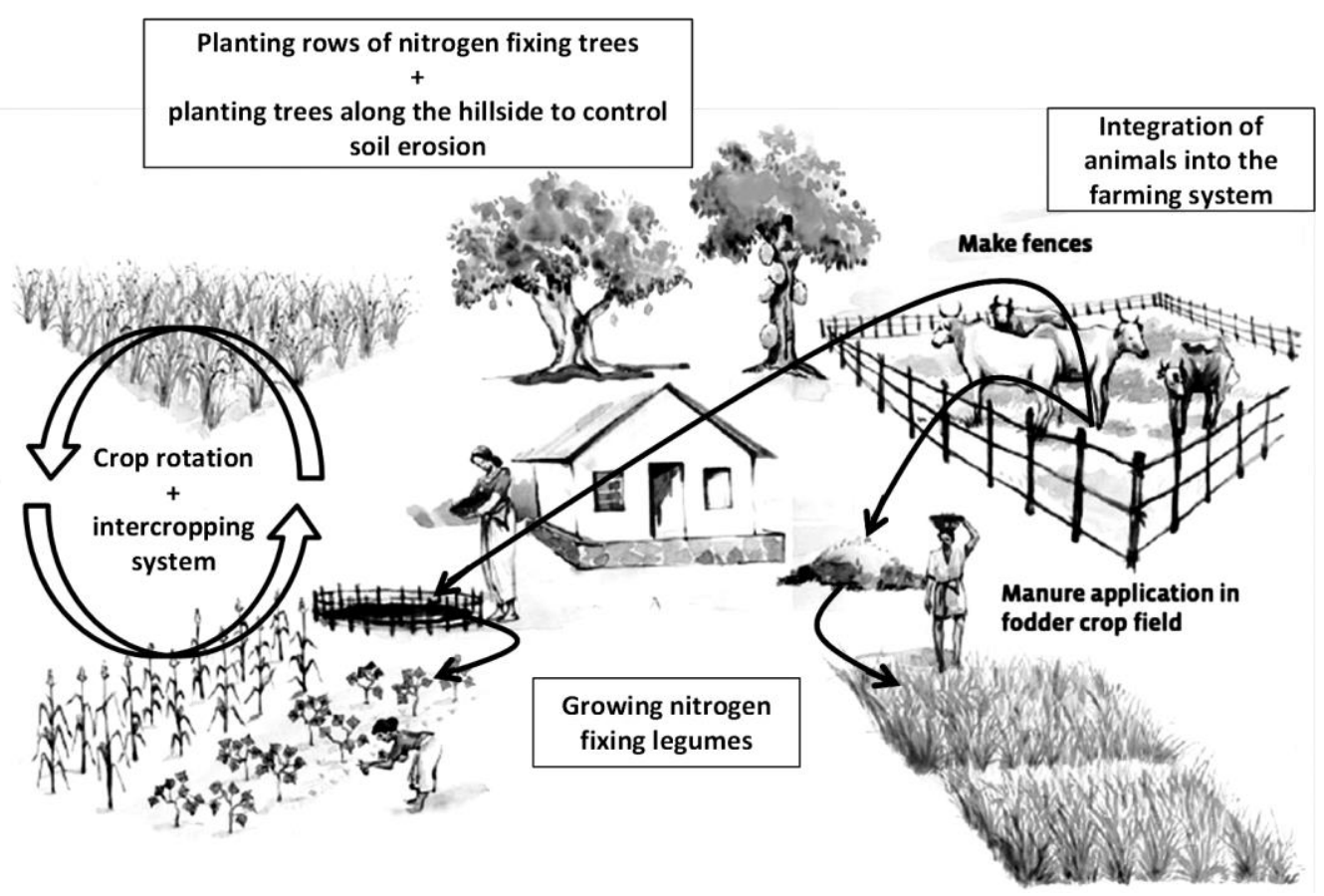

شكل r. اصول استفاده از تناوب در كشاورزى اُركانيك (Gomez and Thivant 2017)

Figure 2. Basics use of crop rotation in organic farming system (Gomez and Thivant 2017)

يوششى مورد استفاده در تناوب زراعى مانند شبدر وحشى، گَونهاى باقلا، گل جعفرى و برخى گياهان خانواده كلم بهعنوان گياهان تله يا دَرآزار (Trap or allelopathic crops) براى نماتدها كاشته مى

شوند (Gomes and Thivant 2017, Dordas 2008). جداسازى مكانى: نيز، با خاكورزى، كاشت گياهان تله در اطراف مزرعه ها، يوشش گياهى طبيعى و كاشت زياهان غيرحساس بين زياهان حساس امكانيذير مىشود. بسيارى از شتههاى حامل ويروسهاى بيمارىزا در صورت كشت جند رديف جاودار، ذرت يا ديخر گياهان بلندقد در اطراف مزرعه ها لوبيا، فلفل يا كدو، ابتدا روى اين كياهان حاشيهاى مىنشينند و از آنها تغذيه مى كنند و به دليل نايايا بودن اغلب ويروسهايى كه شته ناقل آنها است، بسيارى از شتهها قبل از رسيدن به كَاهان اصلى، ويروسهاى مربوط را از دست مىدهند. با استفاده از مالجهاى كاهى، پيلاستيكى يا روغنهاى دوركننده، از كاوش ناقلين ويروس روى ميزبان جلوگيرى مىشود ( Van Bruggen and .(Finckh 2016 مقاومت كياه ميزبان: در كشاورزى أركانيك بيشتر از ارقام با مقاومت ناقص جند زنى استفاده مىشود. استفاده از مقاومت جندزنى در صورتى كه اثر فشار پاتوزن را با روشهاى ديخر مديريتى كاهش دهند، مىتواند مفيد باشد. علاوه بر اين نوع مقاومت زنتيكى، مىتوان از مقاومت القايى ( Induced 
(resistance از طريق اصلاح خاك با استفاده از مواد آلى از جمله كميوست (Yogev et al. 2010) و افزايش فعاليت يا استفاده از باكترىها و قارجهاى تحريك كننده رشد گياه مانند Pseudomonas، Trichoderma Azotobacter با استفاده از تركيبات شيميايى خارجى مانند اسيد ساليسيليك، جاسمونيك اسيد و فسفات يتاسيم نيز حاصل مىشود، اما اين مواد براى توليد محصولات أركَانيك تأييد نشدهاند ( Van Bruggen and

.(Finckh 2016

بهبود و حفظ كيفيت خاك: مهممترين رويكردهاى كشت در نظام كشاورزى أركانيك حول بهبود و حفظ كيفيت خاك مى جرخد. با استفاده از مواد آلى و حمايت از فعاليت كرم خاكى، مىتوان كيفيت فيزيكى خاى را بهبود داد كه در نتيجه باعث افزايش نفوذ آب و زهكشى، كاهش نوسانهاى يتانسيل آب و تشكيل نظامهاى ريشهاى عميق و گسترده مىشود. با گسترش ريشه، حساسيت به انواع قارجهاى عامل يوسيدكى ريشه و يزمردكى مانند ريزوكتونيا، فوزاريوم و ورتيسيليوم و شبه قارجهاى ييتيوم و فيتوفتورا كاهش مىيابد (Leon et al. 2006). اصلاح خاى با استفاده از مواد آلى يا مواد معدنى مجاز طى سال هاى متمادى و كاهش كاربرد كودهاى اضافى در طول رشد محصول، نوسانات در تأمين مواد غذايى را به حداقل مىرساند و باعث بهبود كيفيت شيميايى خاى مىشود. اسيديته خاى و نسبت آمونيوم به نيترات اغلب در اين خاكها بيشتر است. در اسيديته بالاى خاك، آمونيوم مىتواند به آمونياك تبديل شود كه براى اكثر ميكرواركانيسمها سمى است. سطوح نيترات بايينتر و آمونيوم بالاتر مىتواند به كاهش بروز و شدت بيمارىهاى خاكزاد در خاكهاى أركانيك نسبت به معمولى

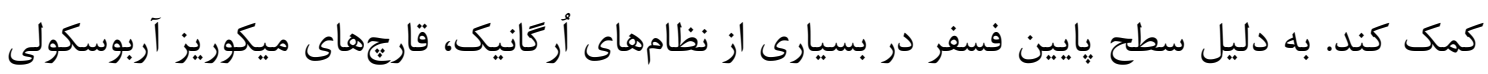
روى ريشه گياهان در خاكهاى با مديريت أركانيك بيشتر (Arbuscular mycorrhizal fungi) مستقر مىشوند و در نتيجه گياهان را در برابر قارجهاى بيمارگر ريشه محافظت مى كنند. كمبود برخى عناصر ديكر ممكن است حساسيت به بيمارىهاى خاصى را افزايش دهند: به عنوان مثال، كمبود يتاسيم خطر يزمرد حساسيت به يوسيدگى ريشه ناشى از ييتيوم مىشود. در خاكهاى أرَانيك به دليل اصلاح خاك با مواد آلى و اسيديته نسبتاً بالا معمولاً كمبود كلسيم مشاهده نشده است ( Larkin 2015, Dordas .(2008 كيفيت زيستى خاى در درجه اول با بركرداندن مواد آلى به خاى بهبود مىيابد. با اين حال، تأثير اصلاح خاى با مواد آلى بر شدت بيمارى، به نوع ماده آلى استفاده شده، نوع تجزيه (هوازى يا بى هوازى)، نسبت كربن به نيتروزن، مقدار ليخنين ماده آلى و مدت زمان سيرى شده از تلفيق ماده آلى 
با خاك بستگى دارد. افزودن بستره آلى به خاك، فعاليت تجزيه كنندهاى ابتدايى، خصوصاً باكترىها

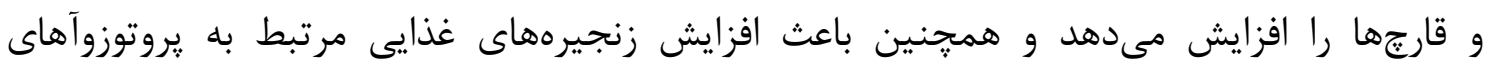

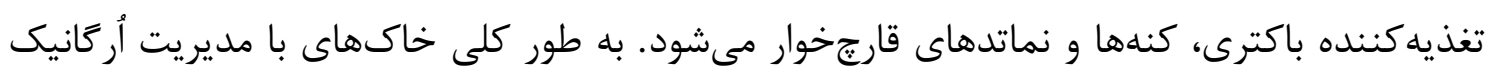
Larkin ) داراى تنوع ميكروبى و جانورى بيشترى نسبت به خاكهاى با مديريت معمولى هستئل . (2015

مديريت محيط هوايى: بسيارى از بيمارىهاى بركى در شرايط مرطوب افزايش مىيابند. براى مهار اين

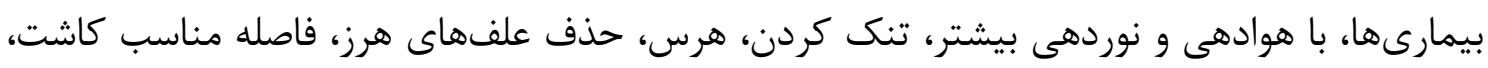
كاشت در جهت باد و يا تهويه بيشتر هواى كلخانه، رطوبت نسبى را كاهش ميى دهند. به عنوان مثال حذف بركى در باغهاى انكور اكنون يك روش معمول براى مهار بيمارىهايى مانند كيك خاكسترى و سفيدى يودرى روى انكور است (Van Bruggen and Finckh 2016). ييشرفت و تقويت مهار زيستى: اكرجه بسيارى از عوامل بالقوه مهار زيستى شناسايى شدهاند، اما تنها

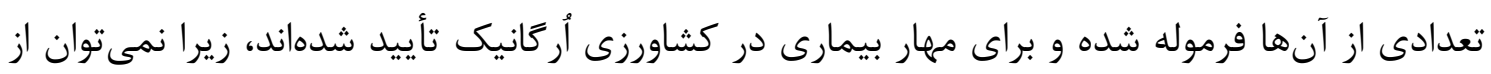

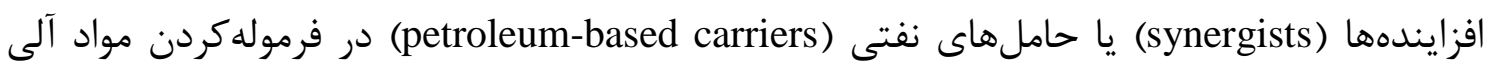
استفاده كرد. به عنوان مثال، كونههاى مختلف Streptomyces Trichoderma، Gliocladium، Bacillus و براى مهار بيماركرهاى خاكزاد استفاده مىشوند. قارجهايى مانند

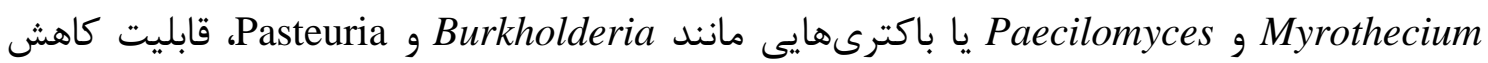
جمعيت نماتدها را به شرطى كه براى استفاده در كشاورزى أركانيك ثبت شده باشنداند، دارند

.(Vannacci and Gullino 2000)

حفظ تنوع گياهان: مىتوان با استفاده از ارقام متنوع، كشت مخلوط رقمها، استفاده از يك گياه

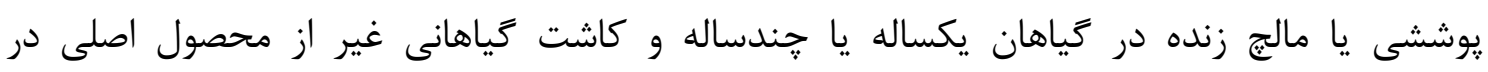

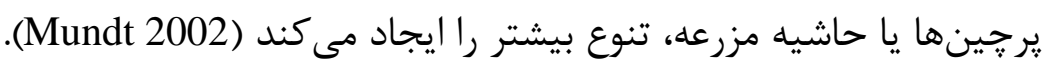

$$
\text { درمان بيمارىها در كشت أركانيك }
$$

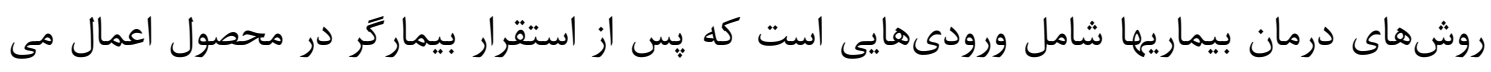

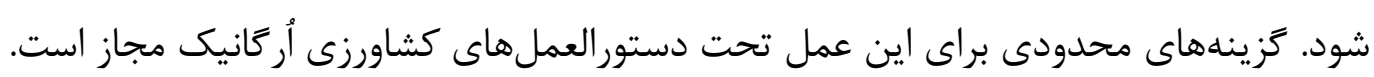

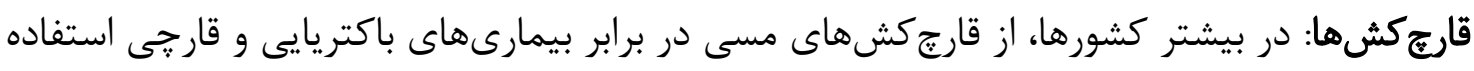

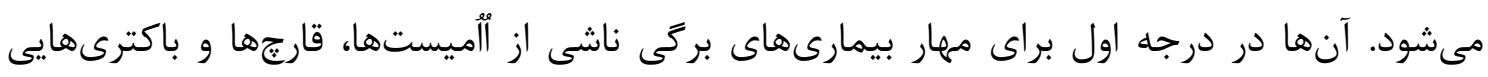

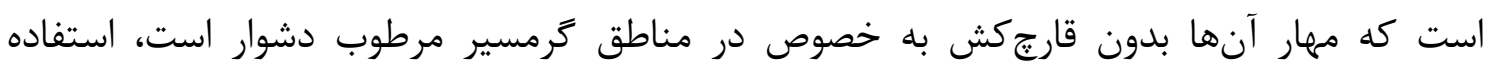

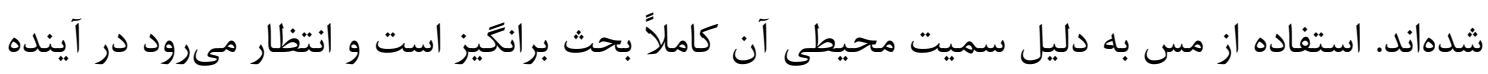


نزديك در ارويا ممنوع شود. قارجكشهاى كو گردى سميت كمترى دارند و به طور گسترده براى مهار سفيدى يودرى در محصولات مختلف و لكه سياه سيب استفاده مىشود. نمكهاى بىكربنات نيز مى

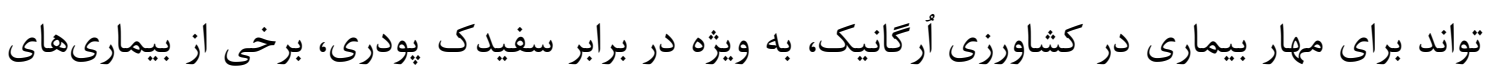

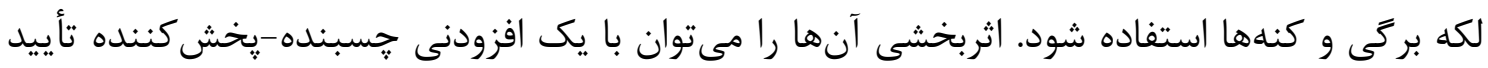
شده مانند صابون يا روغن افزايش داد. برخى از روغنها مانند روغن ماهى، كياهى يا معدنى مىتواند

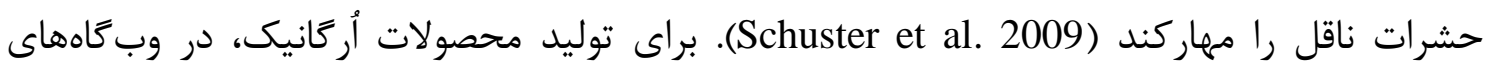
موسسه بررسى مواد أركانيك (Organic Materials Review Institute=OMRI: http://omri.org) و

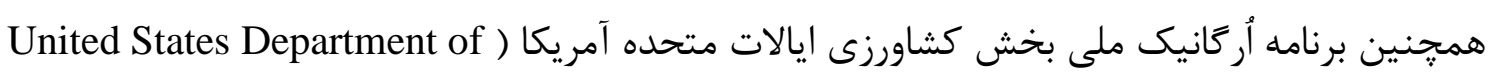
(https://www.ams.usda.gov/about- Agriculture=USDA:National Organic Program: ams/programs-offices/national-organic-program

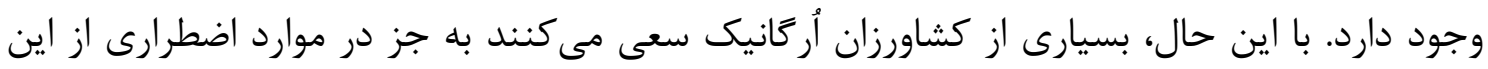
مواد استفاده نكنند. عصارههاى گياهى و ميكروبى: تركيبهاى طبيعى با منشأ ميكروبى و كياهى مىتوانند مستقيماً به

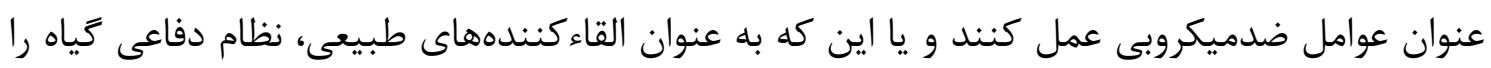
فعال كنند (Gwinn 2018). عصاره گَونهاى مختلف كَياهى مانند عصارههاى يوكا، مركبات و جلبك

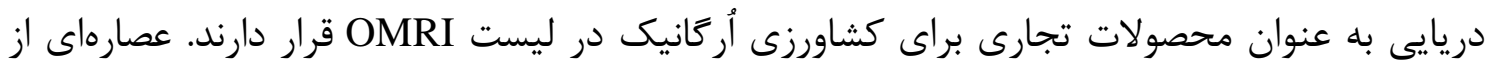
جلبك قهوهاى يا دريايى، لامينارين، در اتحاديه ارويا تصويب شده است. عصارههاى بسيارى از كياهان،

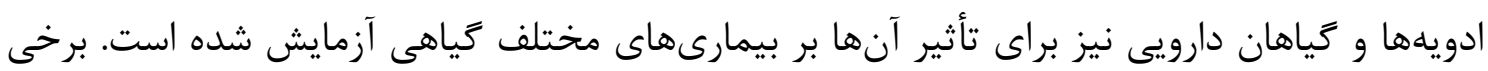

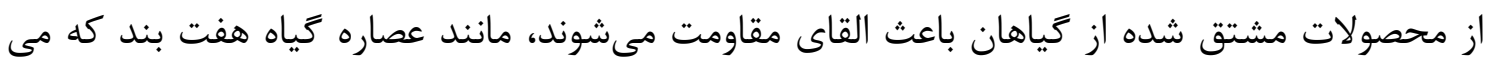
تواند در برابر سفيدك يودرى خيار استفاده شود و به نام ميلسانا (Milsana) ثبت شده است. جندين عصاره كَاهى براى استفاده در برابر حشرات، از جمله ناقلين ويروس فرموله شده است. به

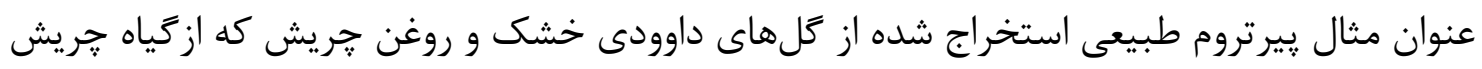
Azadirachta indica

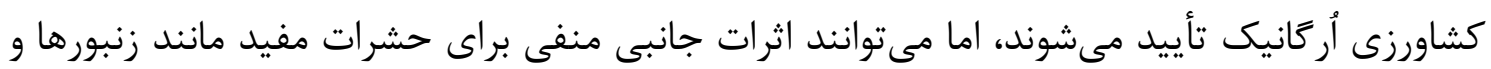

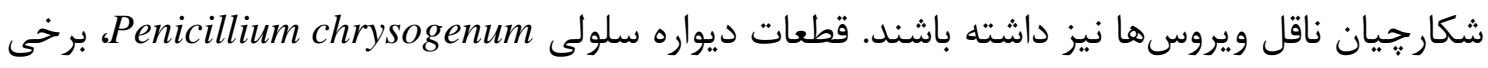
از عصارههاى باكتريايى و عصارههاى كميوست (Scheuerell and Mahaffee 2002) نيز مىتوانند در

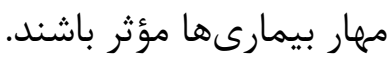




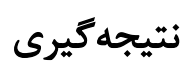

مشكلات دورهزذار به كشاورزى اركانيك مانند كاهش عملكرد، نبودن برنامهاى ترويجى و آموزشهاى لازم براى كشاورزان، عدم وجود مراكز صدور گواهى اُركانيك معتبر، تنگناهاى مربوط به عمليات زراعى، مشكل توزيع و بازاريابى، شرايط متغير جوى، نبود جايكزينهاى طبيعى براى برخى

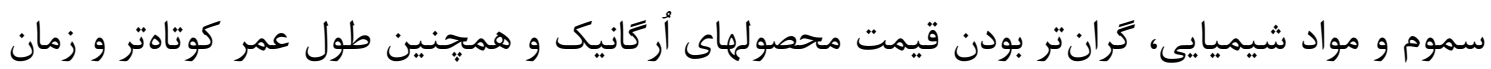
مصرف محدودتر آنها، همكى از جالشهاى كشاورزى أرَانيك محسوب مىشوند. اما پِيامدهاى كشاورزى مرسوم و صنعتى مانند مشكلات زيستمحيطى، عدم توجه به نقاط قوت بومنظامهاى طبيعى و استفاده از آنها در مديريت آفات و بيمارىها، تخريب و استفاده بيش از حد از منابع آب و خاك، به خطر افتادن سلامتى انسان به دليل استفاده از محصولهاى آلوده، همگى حركت به سمت كشاورزى أركانيك را اجتنابنايذير مى كنند.

\section{References}

Cohen MR, Yamasaki H, Mazzola M (2005) Brassica napus seed meal soil amendment modifies microbial community structure, nitric oxide production and incidence of Rhizoctonia root rot. Soil Biology and Biochemistry 37:1215-1227.

Dordas C (2008) Role of nutrients in controlling plant diseases in sustainable agriculture. A review. Agronmy for Sustainable Development 28:33-46.

Furtak K, Gałązka A (2019) Effect of organic farming on soil microbiological parameters. Polish Journal of Soil Science 52:259-268.

Gomez I, Thivant L (2017) Training manual for organic agriculture. Scientific Publishers, India, 105p.

Gwinn KD (2018) Bioactive natural products in plant disease control. In Studies in natural products chemistry. Elsevier 56:229-246.

Harman G (2006) Overview of mechanisms and uses of Trichoderma spp. Phytopathology 96:190-194.

Larkin RP (2015) Soil health paradigms and implications for disease management. Annual Review of Phytopathology 53:199-221.

Leon MCC, Stone A, Dick RP (2006) Organic soil amendments: impacts on snap beans common root rot (Aphanomyes euteiches) and soil quality. Applied Soil Ecology 31:199-210.

Magdoff F (2007 ) Ecological agriculture: principles, practices, and constrains. Renewable Agriculture and Food System 22:109-117.

Mundt C (2002) Multiline cultivars and cultivar mixtures for disease management. Annual Review of Phytopathology 40:381-410. 
Saloum A, Almahasneh H (2015) Effect of soil solarization and organic fertilization on yield of maize (Zea mays L.) genotypes and soil chemical properties. Asian Journal of Agricultural Research 9:173-156.

Scheuerell S, Mahaffee W (2002) Compost tea: Principles and prospects for plant disease control. Compost Science and Utilization 10:313-338.

Schuster DJ, Thompson S, Ortega LD, Polston JE (2009) Laboratory evaluation of products to reduce settling of sweet potato whitefly adults. Journal of Economic Entomology 102:1482-1489.

Shi-Ming MA and Sauerborn J (2006) Review of history and recent development of organic farming worldwide. Agricultural Science in China 5:169-178.

Swer H, Dkhar M S, Kayang H (2011) Fungal population and diversity in organically amended agricultural soils of Meghalaya, India. Journal of Organic Systems 6:3-12.

Van Bruggen AHC, Finckh MR (2016) Plant diseases and management approaches in organic farming systems. Annual Review of Phytopathology 54:25-54.

Van Bruggen AHC, Gamliel A, Finckh MR (2015) Plant disease management in organic farming systems. Pest Management Science 72:30-44.

Vannacci G, Gullino ML (2000) Use of biocontrol agents against soil-borne pathogens: results and limitations. In international symposium on chemical and non-chemical soil and substrate disinfectation 532:79-88.

Willer H, Lernoud J (2019) The World of Organic Agriculture Statistics and Emerging Trends. Research Institute of Organic Agriculture FiBL and IFOAM Organics International, Frick and Bonn. Retrived from https://ciaorganico.net/documypublic/486_2020-organic-world-2019.pdf

Yogev A, Raviv M, Hadar Y, Cohen R, Wolf S, Gil L, Katan J (2010). Induced resistance as a putative component of compost suppressiveness. Biological Control 54:46-51.

Zahir AZ, Arshad M, Frankenberger WT (2004) Plant growth promoting rhizobacteria: applications and perspectives in agriculture. Advances in Agronomy 81:97-168. 